\title{
John Dewey and the Role of the Teacher in a Globalized World: Imagination, Empathy, and 'Third Voice'"
}

\section{ANDREA R. ENGLISH}

Keywords: Dewey, Teaching, Higher Education, Imagination, Empathy, Narrative Arts, Nussbaum, Internationalisation

Reforms surrounding the teacher's role in fostering students' social competences, especially those associated with empathy, have moved to the forefront of global higher education policy discourse (Hénard and Roseveare, 2012; HLG, 2013). According to a report by the OECD, ${ }^{2}$ these reforms are in part driven by the recent rapid increase in diverse populations of students coming together due to government support of student mobility — now a mainstay of global higher education internationalisation policy (Hénard and Roseveare, 2012; ACE, 2015). In this context, reform in higher education teaching has been focused on shifting teachers' practices away from traditional lecture-style teaching — historically associated with higher education teaching - towards student-centred pedagogical approaches, largely because of how the latter facilitate students' social learning (Hénard and Roseveare, 2012, p. 9). In strong support of this shift to student-centred teaching, a 2013 report by the European Commission's 'Higher Level Group on the Modernisation of Higher Education,' explicitly associates 'high-quality teaching' with the development of students' abilities connected to empathy, such as 'intercultural understanding' and 'understanding of different interests, views and ways of thinking' (HLG, 2013, p. 50). ${ }^{3}$ These developments towards learner-oriented higher education teaching may

\footnotetext{
${ }^{1}$ Versions of this paper were presented as invited talks at the "2016 Centennial Conference on Democracy and Education" at the Annual Meeting of the John Dewey Society in Washington D.C., and at the "Workshop on Democracy and Education" sponsored by the Universitaet Wien, Faculty of Philosophy and Educational Sciences and Niederoesteriechische Schule in der Schulentwicklung (NOESIS), in Vienna.

${ }^{2}$ OECD stands for "The Organisation for Economic Co-operation and Development" and consists of the work of 34 member countries, and 70 non-member economies, see http://usoecd.usmission.gov/mission/overview.html.

${ }^{3}$ See also pages p. 32 and 35 . The report draws on terminology from the seven competences of lifelong learners in the European Key Competence Framework. The terminology surrounding ideas of empathy appear to be drawn from one of the key competences, 'Social and Civic Competence,' which describes 'the core skills of this competence include the ability to communicate constructively in different environments, to show tolerance, express and understand different viewpoints, to negotiate with the ability to create confidence and to feel empathy' (EC, 2006). See also the Higher Education Academy's Internationalising Higher Education Framework, which promotes activities of intercultural engagement
} 
offer promising opportunities - and, notably, they reference John Dewey's learning theory indicating his influence. ${ }^{4}$ However, a central problem within these current policy recommendations is that the connection between cultivating empathy and cultivating imagination is not explicitly foregrounded. As a consequence, these recommendations could lead to policies that implicitly place an expectation on teachers which goes unrecognised or misinterpreted, namely the expectation to cultivate students' imagination. I contend that the teacher's task in cultivating the imagination needs to be made visible so that its role in guiding teachers' reflective practices can be critically evaluated by practitioners, theorists, and policy makers alike.

Against this background, I turn to Dewey's notion of imagination to show how imagination is indispensable to all learning, and therefore has a role to play in teaching. For Dewey, imagination can be seen as a 'pathway' to empathy - a connection underscored in a growing body of philosophical and psychological research on empathy ${ }^{5}$. In this paper, I show how imagination is not only deeply connected to empathy, but also critical for gaining intercultural understanding and is a condition for the possibility that, as human beings, we can learn with and from others. Therefore, Dewey's notion of imagination provides significant insight on how to rethink what is needed to create inclusive classrooms in higher education, especially under conditions of cultural, linguistic and religious diversity.

In section one, I provide an in-depth examination of Dewey's notion of the connections between learning, imagination, and empathy. I focus on illuminating how imagination helps us reflectively engage moments of resistance in our experiences especially by aiding our empathetic exploration of the what I call 'the in-between realm of learning,' in which the ideas and views of others emerge. In section two, I turn to consider the teacher's role in cultivating students' imagination and how this connects to fostering dialogue across difference. Drawing primarily on the work of Martha Nussbaum, I examine how teaching through the narrative arts in higher education cultivates the imagination and helps us engage the lives of others. I develop the idea that when teaching productively cultivates imagination, it creates what I refer to as third voice, a different or other 'position' that productively mediates interaction between participants, including teacher and learners. I provide an example from my own teaching experiences to help illustrate how third voice serves to facilitate critical reflection within cross-cultural learning contexts. I close the section by point outing out central challenges teachers in Higher Education face when seeking to facilitate dialogue across difference. In the third and final section, I consider the implications of my discussion for present and future higher education policy on the evaluation of 'quality teaching'.

'underpinned by empathy, sociability and sensitivity to all forms of diversity' in all contexts of higher education institutions. (HEA, 2014)

${ }_{5}^{4}$ See the epigraphs in HLG (2013).

${ }^{5}$ See .for example, Smith, 2011; Prinz, 2011. See also earlier work in philosophy of education, e.g. Gallo, 1991; Greene 1995. 


\section{Exploring within the In-between of Learning: The Role of Imagination in Thinking and Learning}

Dewey's theory of learning provides unique insight into the complex connection between learning, imagination and empathy. Underlying this connection, as I seek to draw out here, is the idea that human experience involves arriving at the limits to our knowledge and ability — it involves an encounter with our own "blind spots." This experience of limitation is constitutive of learning, and imagination is a central human capacity, which helps us navigate this experience and address our 'blind spots' in a way that incorporates others. In order to get at these complex links between learning, imagination and empathy more fully, I address each of these notions in turn, proceeding in three main steps. First, I attend to Dewey's concept of learning as a process he calls a 'reflective experience'. I then turn to examine how Dewey defines imagination, highlighting how it plays a role in fostering reflective exploration within what I refer to as the 'in-between realms of experience'. Finally, I develop the connections between imagination and empathy, by focusing on how imagination, in Dewey's view, is a capacity, which allows us to grasp the world from the situation of others. On this basis, I argue that imagination is central to learning from and with others. This argument in provides the foundation for my view teaching involves the cultivation of the imagination, which I will turn to in part two.

\section{Learning, Thinking and the In-between}

In Democracy and Education, Dewey gives an account of the connection between learning and experience that clarifies how all learning involves encounters with difference and otherness, in which we experience moments of resistance that, in turn, open us up to questioning our takenfor-granted ideas and habitual ways of being. He explains that experience is both active and passive: active, in that it involves an interaction between self and world in which we 'try' something in the world, and passive, in that we 'undergo' something from the world in return (e.g. Dewey, 1916/2008, p. 146-47). Moments of doing and undergoing occur in a range of everyday interactions with the world, from the more mundane - for example, when we grab an object that we thought was smooth, yet it turns out to be rough - to the more significant - for example, when we trusted a friend with a secret and find out it has been shared with others.

Dewey repeatedly uses the example of a child sticking his finger into a flame in order to demonstrate the connection between doing and undergoing, which is central to his concept of

\footnotetext{
${ }^{6}$ I have referred to the experience of limitation elsewhere using the idea of the negativity of one's experience, which connects to a long-standing tradition of philosophy of education (English, 2013). Here, I use the terminology of blind spots metaphorically, because it is particularly useful to capture both the individual aspect of experience - my blind spot is particular to my own learning history - and the interconnection between oneself and the world - I only recognise that I had a blind spot on the basis of an encounter with a world and others that are in some way unfamiliar to me, and thus present me with a limit to my knowledge and experience. See also English 2016a.
} 
learning. The undergoing side of experience is the feeling of a pain of a burn, that resulted from an act of 'doing' something, namely putting one's finger into the fire (Dewey, 1916/2008, p. 146). Without connecting the pain of the burn to the act of touching the flame the child does not learn; however, if the child reflects and considers why his finger was in pain after touching the flame, then the child is beginning a process of learning from the interaction with the world. For Dewey, these basic elements are in all learning processes, whether of an adult or child.

While Dewey's concept of learning is commonly connected to the idea of 'doing' and 'active learning' (and is even referred to as 'learning by doing'), the experience of 'undergoing' is particularly significant for understanding learning in its connection to imagination (which I discuss below). When we 'undergo' this means we have come across something we could not foresee; it 'tells' us that we do not have control, we are not able to correctly anticipate, we do not have accurate foresight, and we are not able to calculate how our interaction with the world will unfold. Resistance tells us that routine and habit are not sufficient to engage the world, because the world is not how we thought it was. These moments in which the world defies our expectations, and we encounter a 'blind spot' mark a beginning of learning. Dewey describes this beginning of learning as an encounter with something unexpected which brings us into a state of 'doubt', 'uncertainty', or 'confusion' in which we ask ourselves, What happened? What went wrong? (Dewey, 1916/2008, p. 155 and 157; English, 2013). These encounters with the unexpected point to the fact that learning begins as a discontinuous moment in experience; this discontinuity arises when we encounter something new and unfamiliar - a new object, idea, concept, or behaviour of another person (English, 2013).

But it is important to note that these beginnings to learning, which arise from our encounter with difference and otherness, are just that, namely beginnings; they do not constitute what Dewey calls a reflective learning experience. Yet still, as beginnings to learning, these moments of discontinuity, or interruption have educative value: such moments offer us the opportunity to take in something new - the new idea or object that initially confuses us - in a way that can transform our thinking and modes of acting. The central question then is, How do we treat experiences of discontinuity and resistance so that they inform our thinking?

In order for these moments of discontinuity to develop into learning processes, we need to make a reflective connection between what we did in the world and how the world responded to us in return. To make a connection between doing and undergoing, we must first explore possible connections through a type of thinking that Dewey calls 'reflection'. 'Reflection,' or 'reflective thinking,' for Dewey, is the form of thinking that takes up the doubt and uncertainty arising from our experience of limitation. Reflective activity is situated in the moment in which we became uncertain and, it actively engages the particularities of that moment, rather than ignoring them or moving on by trial and error. To 'reflect' is to attempt to inquire into the uncertainty and explore it with the purpose of determining what it is that caused us to become uncertain or perplexed: "the perplexities of the situation suggest certain ways out. We try these ways, and either push our way out, in which case we know we have found what we were looking for, or the situation gets darker and more confused - in which case we know we are still 
ignorant' (Dewey, 1916/2008, pp. 155-56). When our thinking processes are so engaged as to try to understand the situation we are in such that we remain in 'suspense' and investigate our own blind spots, then thinking becomes a 'reflective experience' (Dewey, 1916/2008, pp. 152-155). Reflection seeks to illuminate how the self and world relate, that is, it seeks to articulate how the 'change made [to the world] by [our] action' relates to 'a change made in us' (Dewey, 1916/2008, p. 147). By 'reflecting,' that is, by making this 'backward and forward connection' between what we did and what we underwent in consequence, new meaning arises (Dewey, 1916/2008, pp. 146-47). A reflective experience is the term Dewey uses to describe genuine learning processes which entail the back and forth of doing and undergoing and making connections.

While Dewey scholarship has largely recognised that Dewey, like other pragmatists, views thinking as beginning in our moments of doubt and uncertainty, less considered is the educative significance of this moment as an opening, as a space of ambiguity - a space of being between old and new ideas and beliefs. Dewey refers to this space using the idea of the "twilight zone of inquiry" (Dewey, 1916/2008, p. 155; English 2013; English 2016b). Reflective learning experiences are educative because, in them, we reflectively explore this space in order to understand the nature of our interaction with the world. I describe this realm of uncertainty as an in-between realm of learning; it is a space in which we are between old and new, right and wrong, in which we have recognised that old values and beliefs no longer guide us, but have yet not found new ways forward (English 2013; English, 2016b). In this space we can ask new questions that can lead us to discover previously unforeseen connections and associations between things, which can guide how we come to think and act. This process of inquiry, exploration, and discovery requires imagination in order to be fruitful, as I discuss further below.

Before turning to examine Dewey's concept of imagination and how it connects to this 'inbetween realm of learning,' it is worth emphasising a point that will prove particularly relevant to the discussion of imagination: Dewey's concept of learning and its connection to experience, highlights the fact that undergoing the world has moral significance - it points us to our "blind spots" and we must consider these if we want to learn from the world and others. As mentioned, the undergoing aspect of human experience describes the moments in which the world in some way defies our expectations; it resists us in some way. Dewey also refers to these moments as "suffering," a term that more strongly indicates that when the world surprises us, we are affected. Undergoing, or suffering, for Dewey, points to the moments when we 'take in' the world as other. In Art as Experience, Dewey describes the connection between 'taking in' and undergoing the world as follows:

There is $[\ldots]$ an element of undergoing, of suffering in its large sense, in every experience. Otherwise there would be no taking in of what preceded. For 'taking in' in any vital experience is something more than placing something on the top of consciousness over what was previously known. It involves reconstruction which may be painful. (Dewey, 1934/2008, pp. 47-48) 
'Taking in' means taking in difference and newness in a way that is transformative. Taking in arises from undergoing the world in a genuine sense such that it affects us and changes how we think and act, and as Dewey says, this can be 'painful.' The alternatives to 'taking in' the world as different and other is ignoring or escaping the felt resistance, and thus, not learning: we either have a 'zeal for doing,' in which case, we treat resistance 'as an obstruction to be beaten down, not as an invitation to reflection,' or, we undergo to such an extreme that we are led to escape the felt resistance of the world by escaping into 'day dreaming' without the new 'taking root in mind' (Dewey, 1934/2008, p. 51).

Given this, Dewey's concepts of learning as a reflective experience can be viewed as a deep theoretical consideration of how human beings can reflectively take up potentially painful experiences of limitation, which disrupt our habitual and taken-for-granted ways of thinking and being and call upon us to learn. Do we run from resistance and ignore possibilities to learn from otherness or difference, or do we remain in suspense and explore new ways of thinking, acting and being? How we answer this question becomes even more significant in cross-cultural contexts, when we potentially have the opportunity to learn from others' cultures, values, experiences and beliefs that may be different from our own. Imagination plays a critical role in aiding our ability to learn from and with others, as I explore in detail next.

\section{Imagination and the In-between}

Imagination, on Dewey's account, connects specifically to the undergoing side of experience, in which we experience resistance; it helps us take in the world in a way that is called for by 'undergoing'. 7 Our capacity for imagination allows us to dwell in the space of the in-between because it facilitates our ability to extend our thinking beyond the known, and allows alternative ways of seeing and being in the world to emerge in our minds. As I will draw out below, imagination fosters reflective learning experiences; it enriches our thinking and thereby enriches our capacity to explore and understand the perplexity and uncertainty we have encountered within experience.

In his definition of imagination, Dewey draws our attention to this idea of imagination as extending experience by 'taking in' the world: 'Imagination' is not 'the imaginary,' rather it is 'a warm and intimate taking in of the full scope of a situation' (Dewey, 1916/2008, p. 244, emphasis mine). Two contrasts, one explicit and one implicit, come to the fore in Dewey's definition of imagination that point to the connections between imagination and learning: the explicit contrast between imagination and the imaginary and; the implicit contrast between a full scope of a situation and a narrow scope. I turn to the latter point first, and then discuss the distinction between imagination and the imaginary, which will lead into my discussion in art two of the role teaching through the arts to cultivate imagination.

\footnotetext{
${ }^{7}$ On this point, see Rømer (2010), especially pp. 141-143.
} 
In Dewey's definition of imagination above, the idea of the 'full scope of a situation' is contrasted with a more narrow scope that we gain in our everyday personal experiences. By pulling us towards the full scope of a situation, imagination always brings us beyond what Dewey calls 'the scope of personal, vitally direct experience' which is 'very limited' (Dewey, 1916/2008, p. 240). Dewey's notion of imagination as an extension of the direct, personal "here and now" helps us understand imagination as the capacity which allows us to extend our thinking processes into the in-between realm of experience, wherein we are still lost, still uncertain, still searching for ways of understanding our experience of difference. Imagination thus seeks to move us beyond the narrow, limited and the habitual, which arise from repetitive existence. 'Narrowed' experiences, in the Deweyan sense, are experiences that have become 'acclimat[ed] to standardized meaning' (Fesmire, 2003, p. 66). Being wedded to standardized meanings in the world limits our capacity for growth and learning. This frames our thinking so that we merely see the old in the new, rather than allowing the new to be $n e w$, that is, to be unfamiliar, unknown, different and strange — to be the object of learning. ${ }^{8}$ If we go on living within the confines of narrow, direct personal experience, then we never encounter our own 'blind spots.' Without such experiences of limitation, we do not come to question what we have taken for granted, and therefore cannot learn from other human beings (English, 2013). Through imagination, the 'old and familiar things' that we have taken for granted 'are made new in experience' (Dewey, 1916/2008, p. 271). In this way, as Maxine Greene underscores, 'imagination more than any other capacity breaks through the 'inertia of habit' (Greene, 1995, p. 21).

Let us now take a look at the explicit distinction Dewey makes in his definition of imagination above, the distinction between imagination and the imaginary. Dewey's contrast between 'imagination' and the 'imaginary' points to an important connection between imagination and the experience of resistance, that as I discussed, is part of learning. Imagination is not simply the 'imaginary,' that is, it is not being in a state of pure fancy, or daydreaming in a way that has no connection to the situation at hand - what we see, hear, think, remember and feel. Unlike imagination, the imaginary strays too far from our lived experiences and so it does not deal with the material in the world that resists us and defies our expectations, that is, the material of learning and growth: the 'mind stays aloof' toying with material that 'does not offer enough resistance, and so mind plays with it capriciously' (Dewey, 1916/1934, p. 272). Imagination, in contrast, takes up the stuff of experience, directly connecting the moments of resistance that are part of human experience.

Unlike the realm of the imaginary, which is an escape from experience, the realm of imagination opens up as an explicit 'taking in' of the world we have undergone, a world that is new, that is different from what we had experienced before, such that we experience

\footnotetext{
${ }^{8}$ This relates to what German philosopher, J.F. Herbart calls a one-sided person, they always see the old in the new, which means they frame things so that they fit prior conceptions of truth. H contrasts this with the multi-faceted person who can learn from new experiences. (Herbart 1806/1902); see also English, 2013 , p. 20
} 
discontinuity and resistance. Imagination, as 'taking in of the full scope of a situation,' means integrating those moments of the unexpected (which disrupt or interrupt the smooth path of habitual modes of thinking and action) into processes of learning, in turn giving them more meaning. In this way, imagination promotes what Dewey refers to as 'integral experience.' An integral experience is neither aimless, nor arbitrarily restrictive as if forcing us to rigidly remain within certain predefined limits, rather it is an experience of growth towards 'maturation,' or what Dewey calls a 'consummation' (Dewey, 1934/2008, pp. 47-49). For Dewey, this experience is 'aesthetic' in that it does not ignore resistance, but rather it attends to it, and converts 'resistance and tensions [...] into a movement toward an inclusive and fulfilling close' (Dewey, 1934/2008, p. 62). Imagination is essential to aesthetic experiences; it extends our capacity to take in the resistance, tension, conflict and struggle that is initiated by our encounters with those things that are new and different, that are difficult to understand, that contradict our beliefs, cause uncertainty, incite fear, or shut us down emotionally in ways that prevent our ability to learn.

\section{Imagination and Empathy}

Dewey's concept of imagination illuminates the idea that the work of imagination as 'taking in' is an act of empathetically learning from others. It involves taking in the perspectives, feelings and interests of others. As Dewey writes, we do not come to understand another person, even one 'with which we habitually associate,' just by having more information about him or her (Dewey, 1934/2008, p. 339). We come to understand another person and gain 'friendship and intimate affection' when, by way of imagination, our knowledge of the person is integrated into our empathetic viewpoint:

It is when the desires and aims, the interests and modes of response of another become an expansion of our own being that we understand him. We learn to see with his eyes, hear with his ears, and their results give true instruction, for they are built into our own structure (Dewey, 1934/2008, p. 339).

It is this idea that captures what Fesmire calls 'empathetic projection' or empathy, as one of the two central meanings of imagination in Dewey's work (Fesmire, 2003, p. 65). ${ }^{9}$ Empathetic projection is not an act of applying one's own values onto others, but rather of 'taking the attitudes of others,' which 'stirs us beyond numbness so we pause to sort through others' aspirations, interests, and worries as our own' (Fesmire, 2003, p. 65). In this connection between imagination and the gaining of affection towards others, we can see why Dewey uses the terms 'warm and intimate' in describing the sort of 'taking in' of the world that imagination entails - imagination brings us together as human beings. In what follows, this is what I will

\footnotetext{
${ }^{9}$ Dewey's other related notion of imagination that Fesmire (3003) discusses is "the creative tapping of a situation's possibilities" which is connected to 'empathetic projection', but more a part of addressing moral dilemmas in the context of action.
} 
refer to as empathy, even though Dewey, in his time, referred to it as sympathy. ${ }^{10}$ I define empathy as the imaginative seeing of situations from the view of another person, or, as Dewey phrases it, 'imaginatively' putting ourselves 'in the situations of others' (Dewey, 1908/2008, p. 150).

In examining Dewey's notion of imagination as an essential part of the process of learning as reflective experience, the relation between imagination and reflective thinking becomes apparent: they stand in a dialectic relation to each other. As mentioned above, reflective thinking, for Dewey, is a form of thinking that directly addresses the resistance, perplexity and discontinuity in our experiences and connects it to our activity in the world. Imagination, in its act of in taking in the full scope of a situation, inclusive of the ideas and feelings of others, provides us with various ways of understanding the felt resistance of the world, and thus offers us more multifarious and deeper meanings as to what our blind spots may consist in. In offering us this insight into our own blind spots, it extends our understanding of the bearing of these on our future choices, thus feeding our reflective activity. In turn, reflection takes the increased meaning implied in the situation at hand to make more associations between what we did and what we have undergone, thus feeding imagination's further contemplation of 'what ifs'. ${ }^{11}$ Together, imagination and reflection foster learning within the in-between realm. They extend this realm so that within it, we can consider possibilities for understanding ourselves and our relation to the world. Imagination and reflection acting in this dialectic interchange preclude us from simply moving on via a reiteration of our habitual modes of thinking and acting. By calling upon us to consider our blind spots, they engender the sort of change and reconstructive transformation that, for Dewey, is part of the idea of education itself: education 'is that reconstruction or reorganisation of experience which adds to the meaning of experience, and which increases ability to direct the course of subsequent experience' (Dewey, 1916/2008, p. 82).

Dewey's definition of imagination as the extension of experience beyond our narrowed, and habitual world of everyday life makes vivid the fact that without imagination human beings cannot move past the realm of the known and familiar, that is, they cannot learn from others. Imagination extends our thinking so that we can consider and take in that which is beyond what is immediately within our mind's grasp, reshaping what we take for granted as true and known, through the lens of other possible experiences informed by the situation of others. In this way, imagination is, as Thomas Alexander writes, 'temporally complex,' integrating past, present and anticipated future, so that 'activity may unfold in the most meaningful and value-rich way possible' (Alexander, 1993, p. 386). Imagination brings us from known and visible, towards the

\footnotetext{
${ }^{10}$ This move is online with Fesmire's (2003) analysis of Dewey's term, see pp. 65-66. This terminological switch from certain uses of the word 'sympathy' to contemporary uses of empathy are now more common, since the terms have traditionally been associated with one another, and conceptual clarity about their distinctions is often needed with each usage, e.g. Clohesy (2013) in citing Warnock's use of 'sympathy', says she is speaking of what he refers to as 'empathy.' p. 82.

${ }^{11}$ On the connection between imagination and thinking, see Greene (1995); and, Rømer (2010), especially pp. 141, and 143-148.
} 
unknown, invisible, and uncertain that lies beyond our immediate ways of thinking and being, helping us dwell in these spaces of uncertainty as spaces of learning.

Considering all of the above-mentioned connections between imagination and learning, we must also note, finally, that, for Dewey, there is no arrival at the full scope of a situation; imagination helps us seek the full scope of a situation, but it does not ensure we will attain it. Even as we attempt to take in the full scope of experience, we are also always necessarily continuing to grow. As beings that are capable of learning, that is perfectible, or 'plastic,' as Dewey calls it, human beings never arrive at an end-point to knowledge and understanding; there are always things that we could still come to know and learn, and thus there is always a chance that there is yet a fuller scope of the situation than what we presently perceive. ${ }^{12}$ Because we cannot ever know if we are actually taking in the full scope of a situation, our imagination is markedly critical. It is by way of imagination that we try to determine what we may have left out of our present picture of how things are. Imagination helps us ask creative questions to consider wherein our blind spots may lie. To do this well, however, we need to cultivate our imagination. As Alexander notes, for imagination 'to interpret a situation in terms of possibilities in turn requires an organized body of experience upon which to draw. The richer this background is, 'the more nuances and complex our perception of the world is' (Alexander, 1993, p. 386). Therefore, for rich imagination, we need rich experiences, which must be built up in educative learning environments. Given this, the question of how we cultivate imagination - by which methods and in which directions - becomes of vital significance for educators. This is especially true in today's learning environments, wherein there are potentially greater gaps between the cultural experiences of teachers and students, which, without the cultivation of imagination, could hinder participants' abilities to learn with and from one another. ${ }^{13}$ Next, I examine possibilities for cultivating the imagination in Higher Education teaching contexts.

\section{Imagination as 'Empathetic Projection' and the Creation of 'Third Voice': Teaching through the Arts to support Learning across Cultures in Higher Education}

As I have argued, imagination is essential for going outside one's present knowledge and ability to suspend judgement and consider alternative ways of thinking. As Dewey helps us see, imagination connects to empathy; it is a form of 'empathetic projection,' giving us 'access' to a view of the world as others may see it. With this connection to empathy, imagination facilitates transformative learning processes that happen through our interactions with others, and thereby it makes possible our ability to learn with and from others. In this section, I turn to explore the

\footnotetext{
${ }^{12}$ See Dewey's concept of growth, e.g. in Chapter 4 of Democracy and Education (1916/2008).

${ }^{13}$ While intuitively it seems that it would be more easier to empathise with others more familiar with oneself, this is also now supported by recent psychological, neuroscientific research, which shows that acts of empathising with others with whom one knows less, and assumes is very different than oneself, is more difficult than empathising with those one views as more similar (Coplan, 2011, p. 13-14).
} 
role of the narrative arts in cultivating imagination as empathetic projection. I briefly consider Dewey's view of the special place of the arts in enriching our view of the world and our interactions with others. I then draw upon the more recent work of Martha Nussbaum, who, in her well-known theory of human capabilities, places imagination at the centre of the human capacity to understand the experience of others. ${ }^{14}$ With Nussbaum, I consider the special role of the narrative arts in cultivating our imagination. I argue that the narrative arts help cultivate what I call third voice, an important feature of environments that have opportunities for rich crosscultural experiences of learning. To illustrate the meaning of this concept and how it gets realised in practice, I provide an example from my own practice of teaching through the arts in higher education. To close the section, I address central challenges for teaching in higher education classrooms today.

Many thinkers have long considered the arts as significant in cultivating imagination in a way that supports the development of our capacity for empathy. Dewey was no exception, and while he considered all subject areas as having an educative capacity to build our imagination, he granted a special place to the arts. The arts extend our experiences by supplying us with 'organs of vision' (Dewey, 1916/2008, p. 247). Through engagement with the arts we gain new insight and enrich our ways of understanding the world and others around us. The arts have a particular way of helping us experience difference, especially anything that differs from our ordinary everyday world. The arts allow us to 'enter, through imagination and the emotions they evoke, into other forms of relationships and participation than our own' (Dewey, 1934/2008, p. 336). In this way, the arts support 'appreciation' as an 'enhancement of the qualities which make an ordinary experience [...] capable of full assimilation' through the medium of imagination (Dewey, 1916/2008, p. 246, emphasis mine; also, see also, pp. 244-245). Dewey's remarks illuminate the idea that the arts provide us with various 'lenses' for taking in the world of experience, and this means seeing things we had not previously seen; they reveal 'a depth and range of meaning in experiences which otherwise might be mediocre and trivial' (Dewey, 1934/2008, p. 245)

In her work on the arts and imagination, Nussbaum contributes to a way of understanding and educating the human capacity to learn from the other. Similar to Dewey, but without reference to his work, Nussbaum argues, that the arts cultivate our imagination by opening our minds to alternative ways of thinking and to possibilities that we had not previously foreseen. Nussbaum focuses on the narrative arts, describing them as having particular force in opening the mind through imagination. Engagement with stories of others' lives, she argues, allows the reader to become aware of the fact that there are others that think, act, and are subject to different circumstances than the reader may be (Nussbaum, 1997, p. 88).

\footnotetext{
${ }^{14}$ In several of her writings, Nussbaum has articulates ten central human capabilities which she considers essential for a life lived with dignity. Imagination is part of one of these central capabilities, which she describes as 'Senses, Imagination and Thought: Being able to use the senses, to imagine, think and reason - and to do these things in a 'truly human' way, a way informed and cultivated by an adequate education, including and by no means limited to literacy and basic mathematical and scientific training' (Nussbaum, 2006, pp. 75-76).
} 
Nussbaum's argument underscores the idea that our engagement with stories facilitates our gaining of an empathetic view, but it is not gained merely by way of the acquisition of more information about others, but rather by encountering our own blind spots. Central to Nussbaum's theory of the role of the narrative arts in human development is the fact that something previously "hidden from view" is revealed to the reader - that is, the reader becomes aware of that which was in his or her blind spot. Through engagement with the arts, our imagination is sparked and we become aware of the things beyond our immediate perception and beyond what our everyday experience provides. Nussbaum points out that the narrative arts, especially those works that 'unsettle' and 'disturb' our sensibilities, have the ability to reveal to us characters with a 'rich inner life,' one to which we may not typically have access (Nussbaum, 1997, p. 100). Literary scenarios can reveal the inner lives of others as complex, and associated with emotions of 'hope and fear, happiness and distress,' as well as 'traits such as courage, selfrestraint, dignity, perseverance and fairness' (Nussbaum, 1997, p. 90). Learning about the inner lives of others cultivates a sense of wonder and imagination with which we can connect the lives of others in stories to our own everyday 'attempts to explain the world and [our] own actions in it'(Nussbaum, 1997, p. 89). ${ }^{15}$

Nussbaum's discussion of engaging with the narrative arts describes a certain kind of confrontation with difference that is connected to the Deweyan notion of reflective learning processes discussed above. This type of interaction with difference that helps us to think beyond what we know and helps us to imaginatively consider new possibilities. Such interactions initially interrupt us and call upon us to become other to ourselves by questioning our taken-forgranted beliefs (English, 2013). Thus, creating space for imagining the world as different than how we may immediately perceive it in everyday life has educative value: it facilitates our understanding of the fact that things can be hidden from view - that is, that we can have blind spots and are fallible. The recognition of our fallibility can be painful. It makes us vulnerable and unsettled. Yet, I argue that this recognition is a pre-condition for the development of empathy. Empathy requires the capacity to see things from another person's perspective, while maintaining difference between self and other, ${ }^{16}$ and this means genuinely considering the possibility that 'I could be wrong'. When one considers that there can be other views of the world that could enhance one's own view, or even counter it in a way that is productive, one creates openings for 'taking in,' that is, learning from the other.

\section{Creating 'Third Voice’ to support Cross-Cultural Understanding}

Nussbaum's idea of texts as having the capacity to reveal to us what is 'hidden from view' hints at what I am calling the creation of third voice. The third voice is the voice offered through the text that is in some way other' than the voices represented in any particular group. Third

\footnotetext{
${ }^{15}$ Here, Nussbaum is referring to children gaining a sense of wonder through stories, but as a principle of how the narrative arts work to cultivate imagination, the principle applies to people of any age.

${ }^{16}$ See Gadamer's (1988) who describes this idea of empathy, p. 69. See also von Wright (2002).
} 
voice is educative in that it offers us insight into what may reside within our blind spots, that is, the things we do not know, cannot see and have difficulty imagining on our own without the aide of the text. In what follows, I give an example from my own teaching showing how this third voice was created and how it facilitated intercultural dialogue and learning. The teaching and learning that I detail below was not part of any formal self-study, or action research, or intended to be research of any kind, rather it is only my best attempt at reflecting my time in a class with students, that, looking back, I would now describe as one in which all participants (the students and $\mathrm{I}$, as the teacher) increasingly developed empathy for one another through the imaginative experience of third voice.

In my several years of experience teaching in higher education, prior to the classroom situation I describe here, I had been actively developing a pedagogical approach to teaching philosophy of education through the arts using drama, film, music, visual arts, literature and more. As my classrooms became more diverse with regard to the linguistic, religious and cultural backgrounds of the students, I began to experiment more with approaching aspects of the subject matter using the narrative arts, especially autobiographies. In one of my courses in particular, I saw how created openings for thinking, imagination as empathetic projection and reciprocity that took place between the students, and between the students and me, that I had not experienced without this approach. The course focused on the concept of 'critical thinking,' and we read from the tradition of Critical Theory, including works by Theodor Adorno and Hannah Arendt. In order for students to understand the history and the lives behind these thinkers' ideas, I assigned the autobiography of Walter Benjamin, which is written as a series of episodes from his memories of childhood in early $20^{\text {th }}$ Century Berlin, to be read alongside the often dense philosophical ideas presented in the other texts. ${ }^{17}$

In the beginning of the course, students seemed divided, as is often the case at the beginning, but when students of diverse backgrounds are present, the division, in my experience, tends to come along lines of speaking. Those from the dominant culture and country spoke freely, and appeared comfortable questioning my views and the subject matter, and those from other backgrounds were mostly silently listening. ${ }^{18}$ In this class, as in many others I had had, there was a mix of male and female international students, who self-identified ${ }^{19}$ as Muslim, and who were not native speakers of the national language as well as male and female 'home' students, who spoke the national language as a mother tongue, some of whom indicated having

\footnotetext{
${ }^{17}$ Walter Benjamin was born in Germany, and lived from 1982-1940. His autobiography (2002) was written during the years 1932-1938 when he was in living in exile.

${ }^{18}$ This difference is not simply due to linguistic ability although that can of course be a contributing factor. But, there are other reasons for this phenomenon, one main one being that in cross-cultural contexts, students' and teachers' can be guided by different norms and values, including those that function in the daily operations of classrooms, such as notions of the role of teacher, the role of students, and associated ideas of authority or respect that have consequences for when a person feels it is right to speak and when it right to listen.

${ }^{19}$ What I mean by 'self-identified' is that the students referred to themselves as Muslim during the course.
} 
secular or Christian upbringing. I do not identify with a particular religion, was not raised within a particular religious context, and I was not a native of the country in which I was teaching. In mentioning this, my intent is not to reduce the students, or myself, to these categories, but rather my intent is to provide background to a situation that offers different kinds of challenges to teachers than those faced within culturally and religiously homogeneous classroom contexts. These challenges include, among other things, knowing how to ensure that all students are included and able to feel a sense of being an equal participant in the classroom environment. In this class, just as in others with similar conditions of diversity, I noticed the atmosphere was one of students appearing distant and unfamiliar with one another. I learned from experience that, left unattended, unwanted power structures could develop implicitly and hinder educative dialogue and learning between students.

Each week as we read Benjamin's autobiography, I provided students with the option of choosing how they would share their thoughts about his world, using an activity called 'Reading Circles,' which allows student to take on different reading roles to engage a text. For one of these roles, students had the option of providing a non-linguistic, artistic response to the text, which they would bring to class and show to others as a basis for full class discussion. One student created an artwork accompanied by music to illuminate Benjamin's image of childhood. Another brought photographs of her return to her birth country to discuss the idea of 'home' and the experience of being an outsider in a new place. Another student brought an apple pie that she had baked to represent a difficult experience from childhood that she recalled when reading Benjamin's story, and yet another designed an elaborate labyrinth image detailing the complexity of being lost, which was an interpretation of the thread running through Benjamin's life story.

As the weeks proceeded, unexpectedly, students not only began to imagine and understand the historical context of the lives of Benjamin and the other authors we were reading, but by discussing the similarities and differences between their worlds and his, they also began to identify ways they were similar and different from one another, ways that cut across cultural norms. Over time, they became closer with and more trusting of one another and me. ${ }^{20} \mathrm{I}$ explain the reason for this now, looking back, as a result of an 'expanded space' that was created by the cultivation of the imagination as an empathetic projection into the world of others. In understanding how they shared, and did not share, experiences with a third - an other, Walter Benjamin - who was neither 'me' nor 'you,' and who was not physically part of our classroom, the students began to reconfigure and expand our space together, to a space which included all of us, Benjamin, the other authors, and those in the world who were represented by them, especially those who experienced injustice. ${ }^{21}$ Our classroom became a place where students

\footnotetext{
${ }^{20}$ I say this because of the more personal kinds of sharing that took place over time, and also because of interests shown to continue to study with me, among other things.

${ }^{21}$ In an interesting discussion of space, Simon Marginson (2010) discusses how creating 'space' is connected to imagination: 'Space is plastic...In many respects the spatial form that we inhabit are
} 
began to reflect upon and critique their own experiences and upbringing, and each of them identified failings in how they were educated, including problematic standards of historical truth, ideas of human rights and justice, and restrictions on freedom of inquiry.

Through this example, I seek to highlight how literature, especially the literary form of autobiography, has the capacity to create third voice, a voice that is otherwise not present in the classroom. Third voice has the function of inspiring other 'voices,' those views and ideas that are beyond the realm of our direct experiences, and may not have come about without initiation from the third voice. These other voices were represented in students' responses to the text, artistic responses that allowed for increased openings in the minds of the others in the room (myself and the other students). Third voice does not need to be created through story, though I see story as particularly productive. Rather, it can be created through any material that pulls participants towards the creation of a shared horizon of meanings and facilitates understandings of what it means to be human. In this way third voice inspires empathy as 'the desirable quality [that] is more than mere feeling; it is cultivated imagination for what [people] have in common and a rebellion at whatever divides them' (Dewey, 1916/2008, pp. 127-128; see also Dewey 1934/2008, p. 275).

Third voice enhances relationships and participation by initiating a move from thinking to thinking together. In creating new openings for new perspectives, the third voice leads to communicatively thinking together and exploring our blind spots as a group, which in turn leads to the discovery of additional pathways for thinking. It allows us to imaginatively extend our experiences of the present world into a world that is 'hidden from view.' As members of the group respond to this extension and creatively address the resistance felt within it, they offer others a way to extend their experiences. When teachers create 'third voice' they foster imagination, which Greene sees as vital to use 'in a search for openings without which our lives narrow and our pathways become cul-de-sacs' (Greene, 1995, p.17). The third voice mediates relationships between teacher and learner and between learners such that all, in different ways, learn with and from each other.

In this class, I aimed for the students to understand critical thinking. What actually happened was that not only did they understand it, they began to enact it. A traditional thinker might ask, what does "apple pie" have to do with higher education? In this case, it allowed one student to connect to a world she previously knew little about, and in doing so, she was able to creatively reinterpret the earlier oppressive experience of her youth. By providing students with opportunities to see other possible ways of viewing themselves and others through extended 'organs of vision,' they become critical in productive ways. Dewey describes,

a sense of possibilities that are unrealized and that might be realized are when they are put in contrast with actual conditions, the most penetrating 'criticism' of the latter that can be made. It is by a sense of possibilities opening before us that we become aware of

brought into being by human activities: by our imaginings and productions, by the ways we organize and govern ourselves" (p. 155). 
constrictions that hem us in and of burdens that oppress. (Dewey, 1934/2008, p. 349, emphasis mine)

Upon reflection, this opening is what I recognised in my students.

One of the central challenges teachers face when creating classrooms that allow students to engage across linguistic, cultural and religious diversity, is to help students make the move from 'thinking' to 'thinking together'. Dialogue and engagement with the arts is central to supporting this move. In my own courses, through communicating about students' linguistic and artistic contributions inspired by autobiographies, or also artworks, films, photographs and other forms of art, students support the critical growth of shared meanings and understandingsincluding understandings of feelings, ideas, hopes, and fears - that is cultivated by imagination. ${ }^{22}$ But these shared meanings are not a result of conformity to the majority, nor can finding it be forced by a teacher. Rather they result from sharing in 'the arts of living,' sharing in 'communication and participation in the values of life by means of the imagination' (Dewey, 1934/2008, p. 339; see also Dewey, 1925/2008, p. 132). Such communication and participation is the condition for the possibility to learn in groups with others in any discipline. What is learned in educative peer-interaction, aside from any particular disciplinary knowledge, is how to have an experience with integrity, an experience in which self and others - one's own and others' ideas, questions, feelings, interests, experiences, concerns, shifts in perspective - are treated as valuable.

To accomplish all this, also requires, what Deborah Britzman calls 'pedagogic imagination,' with which educators imagine the relations between what is and what is possible within interactions with students (Britzman, 1991, p. 87; see also Griffiths, 2014). Imagination allows us to reflectively explore within the 'in-between realm of learning,' wherein the problem may not be determined, the paths and possibilities not fully recognised, where we have undergone something, but do not yet fully understand our experience and have not yet devised a way out. This affective, moral, and cognitive space is not a space seeking immediate resolution but seeking further openings in the mind. ${ }^{23}$ Imagination is educative because it functions not only to help us conceive of concrete possibilities, but also to conceive of the possibility of possibility, that is, that there could be more still out of my view, still within my blind spot.

\footnotetext{
${ }^{22}$ Although my purpose in this paper was not to discuss assessment, I can say that I do assess some of these assignments are assessed, while others serve the purpose of fostering in-class discussion. Mary Ryan (2012) gives a very insightful discussion of how providing students with opportunities for discursive and performative (including dance, music and drama) modes of reflection can help them connect to the discipline in higher education courses. She also discusses how to assess these modes of reflection. She argues that providing students to demonstrate reflection through diverse modes, gives each student a chance to showcase individual communicative strengths.

${ }^{23}$ On this point see Burbules (2007), who discusses the productive spaces of the 'in-between' that are created between teachers' intentions and students' interests and which constantly need to be 'renegotiated' and can 'never rest static'. This idea is part of Burbules several works on doubt and the inbetween.
} 


\section{Conclusion: Implications for Higher Education Policy}

As member states in the European Union press forward to professionalize higher education teachers by 2020, and at the same time, create plans for evaluation of quality teaching practice, it is critical that teachers understand the full expectations embedded within these policies. From my discussion, it should be clear that I believe a conscious move in higher education policy towards dialogic classrooms (which support group learning) and away from transmissive forms of teaching - (whether in lecture format or not) in general is positive. Such policies have the potential to support teachers in building cooperative and inclusive classrooms, which foster listening and sensitivity towards others. But, there are other trends in global educational policy that may be compromising these goals, namely the trend towards international comparative data in higher education. The sorts of policies that have adversely affected primary and secondary schools, which place schools in public competition with one another, and make teachers' jobs dependent upon test outcomes are soon going to be taken up in higher education, albeit with a slightly different face. The United Kingdom, for example, has developed the "Teaching Excellence Framework [TEF]," as part of its reform agenda (DBIS, 2016). Although the TEF is still in planning and piloting phases, it appears to be set to publicise ratings of the evaluation of teaching quality within UK universities, in an effort to facilitate competition between universities for student enrolment. The problem with this is not the evaluation of teaching per se, which is necessary and valuable for teachers' growth and professionalisation. Rather, the problem that I suspect will arise, is the same one that has arisen in primary and secondary schools in many parts of the world, including in the UK. Namely, the problem is that the criteria according to which external evaluators evaluate teaching quality will be those that are associated with transmissive - direct lecture-style teaching, which furnishes clear, organised, pre-packed easily digestible bits of knowledge measurable in standardised ways - and those that are associated not with dialogic, active teaching and learning. The latter is much harder to assess; when it is successful, it includes the less visible, moral and ethical dimensions of teaching that are engaged when teachers cultivate imagination, experimental and critical thinking, and the building of empathetic relationships across difference.

Dewey scholar, Robert Boostrom recently wrote, "our world, our culture, our selves depend on playful, fanciful, arbitrary, dangerous imagination" (Boostrom, 2014, p. 92). Imagination is dangerous to those who do not wish to see diverse groups come together, think together, communicate and cooperate in democratic, educative ways. It was not just in Dewey's time, but also one hundred years later in our own, that our world becomes "uncivil because human beings are divided into non-communicating sects, races, nations, classes and cliques" (Dewey, 1934/2008, p. 339). Understanding imagination, as I have suggested here, can help us understand 
how, as a group, teachers and learners become uncertain and imagine possibilities, an experience that is in itself educative. ${ }^{24}$

\section{References}

American Council on Education (ACE) (2015) Internationalizing Higher Education Worldwide: National Programs and Policies. (Washington DC, ACE).

Alexander, T. (1993) John Dewey and the Moral Imagination: Beyond Putnam and Rorty toward a postmodern Ethics, Transactions of the Charles S. Peirce Society 29:3, pp. 369-400

Benjamin, W. (2002) Berlin Childhood around 1900. in: Walter Benjamin: Selected Writings, Vol 3, pp. 344-413 (Cambridge, Belknap Press)

Boostrom, R. (2014) The Dangers of Imagination, in: Experiencing Dewey: Insights for Today's Classrooms. Breault, D.A. and Braeult, R. (eds). pp. 91-92 (New York: Routledge).

Britzman, D. (1991) Practice Makes Practice: A Critical Study of Learning to Teach (New York, SUNY Press).

Burbules, N. C. (2007) Doubt and Educational Opportunity. http://faculty.ed.uiuc.edu/burbules/papers/dep.html (accessed on: August 18, 2007)

Clohesy, A. M. (2013). Politics of Empathy: Empathy, Solidarity, Recognition. Abingdon: Routledge.

Coplan, A. (2011) Understanding Empathy: Its features and Effects, in: Coplan, A. \& Goldie, P. (eds). Empathy: philosophical and psychological perspectives (Oxford: Oxford UP), pp. 318.

DBIS (2016). Teaching Excellence Framework. Technical Consultation For Year Two(London: Department for Business, Innovation and Schools)

Dewey, J. (1916/2008). Democracy and Education, in: The Collected Works of John Dewey: The Middle Works, Jo Ann Boydston (ed.) Vol. 9. (Carbondale, Southern Illinois UP).

${ }^{24}$ I would like to thank the following colleagues for conversation we have had that have facilitated my thinking in this paper: Mordechai Gordon, Leonard Waks, Morwenna Griffiths, Carolin Kreber, Sue Chapman, Holly Linklater, Steven Fesmire, Neda Forgani-Arani, Stefan Hopmann, Dietrich Benner, Timothy Lensmire, and all the participants who provided feedback at my talks. I would also like to thank the blinded reviewers for their thoughtful feedback on the paper. 
Dewey, J. (1925/2008) Experience and Nature, in: The Collected Works of John Dewey: The later Works, Boydston, J.A. (ed.), Vol. 1. (Carbondale: Southern Illinois UP).

Dewey, J. (1934/2008) Art as Experience, in: The Collected Works of John Dewey: The later Works, Boydston, J.A. (ed.), Vol. 1. (Carbondale: Southern Illinois UP).

Dewey, J. and Tufts, J. (1908/2008) Ethics, in: The Collected Works of John Dewey: The Middle Works, Boydston, J.A. (ed.), Vol. 5. (Carbondale: Southern Illinois UP).

English, A. R. (2013) Discontinuity in Learning: Dewey, Herbart, and Education as Transformation (New York: Cambridge UP).

English, A. R. (2016a) Dialogic Teaching and Moral Learning: Self-Critique, Narrativity, Community and 'Blind Spots'. Journal of Philosophy of Education, 50, p. 160-276.

English, A. R. (2016b, in press). The In-between of Learning: (Re)valuing the Process of Learning, in: Dewey in Our Time: Learning from John Dewey for Transcultural Practice. Cunningham, P. J. and Heilbronn, R. (eds.) (London: Institute of Education Press).

EPEC (2006) Recommendation of the European Parliament and of the Council, Official Journal of the European Union. URL: http://eur-lex.europa.eu/legalcontent/EN/TXT/?uri=CELEX:32006H0962 (Accessed on: May 20, 2016).

Fesmire, S. (2003) John Dewey and Moral Imagination: Pragmatism in Ethics. Bloomington: Indiana University Press.

Gadamer, H-G. (1988) “On the Circle of Understanding” In: Hermeneutics versus Science? Three German Views. Notre Dame: U. Of Notre Dame Press.

Gallo, D. (1991) Educating for Empathy, Reason and Imagination, in: C Witherell \& N. Noddings (eds), Stories Lives Tell: Narrative and Dialogue in Education. (New York, Teachers College Press).

Greene, M. (1995) Releasing the Imagination: Essays on Education, the Arts, and Social Change, (New York, Jossey-Bass Publishers).

Griffiths, M. (2014) Encouraging Imagination and Creativity in the Teaching Profession, European Educational Research Journal, 13,:1, pp. 117-129. 
Hénard, F and Roseveare, D. (2012) Fostering Quality Teaching in Higher Education: Policies and Practices. Report of the OECD. URL:

https://www.oecd.org/edu/imhe/QT\%20policies\%20and\%20practices.pdf (Accessed on: January $15,2016)$

Herbart, J.F. (1806/1902) The Science of Education, in: The Science of Education, its General Principles Deduced from its Aim, and The Aesthetic Revelation of the World, Henry M. Felkin and Emmie Felkin (trans.) (Boston: D. C. Heath \& Co.)

Higher Education Academy (HEA) (2014) Internationalising Higher Education Framework. (London: HEA).

Higher Level Group on the Modernisation of Higher Education (HLG) (2013) Report to the European Commission on Improving the quality of teaching and learning in Europe's higher education institutions. URL:

http://ec.europa.eu/education/library/reports/modernisation_en.pdf (Accessed on: January 15, 2016)

Marginson, S. (2010) World in: Murphy, P., Peters M. A., and Marginson, S. (eds.) Imagination: Three Models of Imagination in the Age of the Knowledge Economy. (New York, Peter Lang).

Nussbaum, M. C. (1997) Cultivating Humanity. A classical defence of reform in liberal education (Cambridge, Harvard UP).

Nussbaum, M. C. (2006) Frontiers of Justice. Disability, Nationality, Species Membership. (Cambridge, Harvard UP).

Prinz, J. (2011) Is Empathy necessary for Morality? in: Empathy: philosophical and psychological perspectives, Coplan, A. \& Goldie, P. (eds.), pp. 211-229. (Oxford: Oxford UP).

Rømer, T. A. (2010) Imagination and Judgment in John Dewey's Philosophy: Intelligent transactions in a democratic context. Educational Philosophy and Theory, 44:2, pp. 133-150

Ryan, M. (2012) Conceptualising and teaching discursive and performative reflection in higher education, Studies in Continuing Education, 34:2, pp. 207-223, DOI:

10.1080/0158037X.2011.611799 
Smith, M. (2011) Empathy, Expansionism, and the Extended Mind, in: Empathy: philosophical and psychological perspectives, Coplan, A. \& Goldie, P. (eds.), pp. 99-117. (Oxford: Oxford UP).

von Wright, M. (2002). Narrative Imagination and Taking the Perspective of Others. Studies in Philosophy and Education 21, pp. 407-416. 